\title{
THE EFFECT OF PLASMA ON THE IN VITRO UPTAKE OR BINDING BY HUMAN RED CELLS OF RADIOACTIVE I-131 LABELED L-THYROXINE AND L-TRIIODOTHYRONINE
}

\author{
By K. R. CRISPELL, SHIRLEY KAHANA, AND HARRY HYER \\ (From the Department of Internal Medicine, University of Virginia School of Medicine, \\ Charlottesville, Va.)
}

(Submitted for publication August 5, 1955 ; accepted September 28, 1955)

Thyroxine is bound to a serum protein which appears in the electrophoretogram just ahead of alpha-2 globulin (1-4). Triiodothyronine also associates with this thyroxine binding globulin (T.B.G.) but can be displaced readily with thyroxine while triiodothyronine will not readily displace thyroxine. Deiss, Albright, and Larson (5) suggested that the firm binding of thyroxine to T.B.G. might account for the slower rate of disappearance of thyroxine from the plasma as compared to triiodothyronine.

The purpose of this paper is to report studies on the in vitro uptake or binding by human red cells of radioactive I-131 labeled sodium iodide, human serum albumin, triiodothyronine, and thyroxine. We propose to show that the binding of L-thyroxine by plasma is one of the limiting factors in the uptake or binding of this substance by the human red cell. The uptake or binding of L-triiodothyronine is limited to a lesser degree by plasma binding and is consistently greater than the uptake or binding of L-thyroxine.

\section{MATERIALS AND METHODS}

Blood was obtained from healthy human volunteers in heparinized syringes and the cells separated from the plasma by centrifugation. Stock solutions of radioactive (I-131) labeled sodium iodide, human serum albumin, ${ }^{1}$ L-thyroxine, ${ }^{1}$ and L-triiodothyronine ${ }^{1}$ were diluted with normal saline solution so that two milliliters of the diluted solution contained approximately $2 \times 10^{2}$ counts per minute. Two milliliters of each solution was placed in a test tube and the radioactivity measured in a deep well scintillating counter. Two milliliters of unwashed red blood cells were then added to each of the solutions,

1 Obtained from Abbott Laboratories, North Chicago, Ill. The radioactive human serum albumin (RISA) was kindly furnished through the courtesy of Dr. Donalee S. Tabern. Two milliliters of the diluted solutions contained approximately $2.5 \times 10^{-4}$ micrograms of L-thyroxine or L-triiodothyronine. mixed well, and incubated in a water bath at $37^{\circ} \mathrm{C}$ for an arbitrary period of 30 minutes. The tubes were then centrifuged, supernatant removed, the cells were washed and recentrifuged three times. The supernatant removed and the radioactivity remaining with the red cells was determined and was expressed as a percentage uptake of the original radioactivity. The same procedure was repeated using red blood cells which had been washed three times with normal saline before adding them to the radioactive solutions. (These will be referred to as washed cells.)

Radioactive (I-131) labeled sodium iodide, L-thyroxine, and L-triiodothyronine were dissolved in human plasma (obtained from the Blood Bank) and the same procedure described for the saline solution was carried out using both "washed" and "unwashed" red blood cells.

Two milliliters of plasma were incubated in a $\mathrm{H}_{2} \mathrm{O}$ bath at $37^{\circ} \mathrm{C}$ for 30 minutes with 0.1 milliliter of an alkaline solution of stable L-thyroxine containing 4.5 micrograms per milliliter. Varying amounts of this plasma $(.02 \mathrm{ml}$ to $0.5 \mathrm{ml})$ were added to tubes containing $2 \mathrm{mil}-$ liliters of radioactive (I-131) labeled L-thyroxine in normal saline (previously counted) and 2 milliliters of "washed" red cells were added immediately, mixed gently, and incubated in a water bath at $37^{\circ} \mathrm{C}$ for 30 minutes. At the end of 30 minutes the tubes were centrifuged, the supernatant removed, and the cells washed three times with normal saline. The amount of radioactivity remaining with the red cells was determined and expressed as described previously. The same procedure was repeated using radioactive L-triiodothyronine instead of radioactive $\mathrm{L}$-thyroxine.

Two milliliters of unwashed red cells were incubated at $37^{\circ} \mathrm{C}$ for 30 minutes with 50,100 , and 150 micrograms of stable L-thyroxine dissolved in $0.1 \mathrm{ml}$. of $.02 \mathrm{~N}$ sodium hydroxide. The above mixture was then incubated with radioactive I-131 labeled L-thyroxine for $30 \mathrm{~min}$ utes at $37^{\circ} \mathrm{C}$. The amount of radioactivity remaining with the red cells was determined and expressed as described previously. The same procedure was repeated using 100 micrograms of stable L-triiodothyronine ${ }^{2}$ instead of L-thyroxine.

In all of the experiments where an alkaline solution

2 Kindly furnished by Dr. Arthur Heming of Smith, Kline, and French Laboratories, Philadelphia, Peninsylvania. 
HUMAN RED CELL UPTAKE WITH RADIOACTIVE MATERIAL IN SALINE

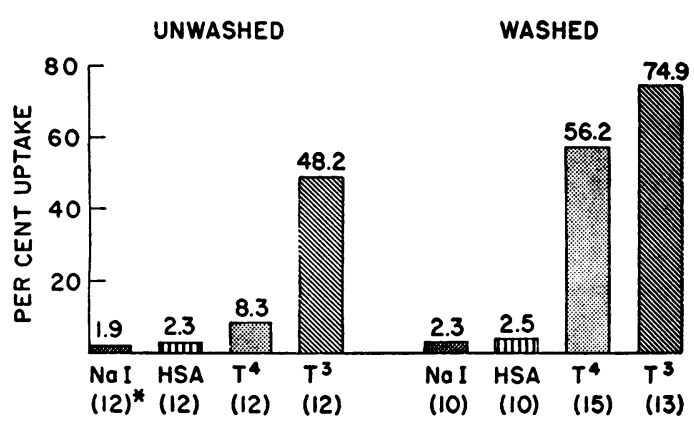

* No. of determinations

$$
\begin{aligned}
\text { NaI } & =\text { Sodium Iodide } \\
\text { HSA } & =\text { Iodinated Human } \\
T^{4} & \text { Serum Albumin } \\
T^{3} & =L \text { - Thyroxin }
\end{aligned}
$$

Fig. 1. A Comparison of the Percentage Uptake of Washed versus Unwashed Red Cells When the Labeled Materials were Dissolved in Normal Saline

of stable L-thyroxine was used a control was set up using the alkaline solution without thyroxine. The radioactivity remaining with the red cell was not due to absorption of the radioactive L-thyroxine or L-triiodothyronine as less than one per cent of the activity will adhere to the glass test tube after saline washings.

\section{RESULTS}

Unwashed red cells-Radioactive tracers in normal saline solution

The percentage uptake by or the percentage of radioactivity remaining with the unwashed red cells was negligible with both radioactive I-131 labeled sodium iodide and human serum albumin. The uptake of labeled L-thyroxine was consider-

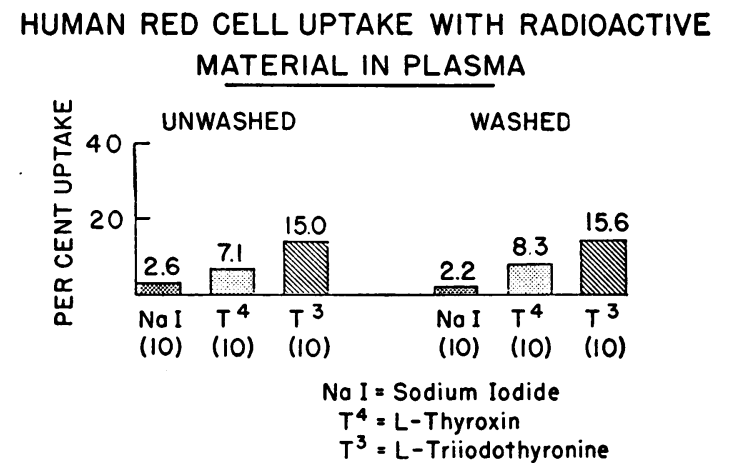

Fig. 2. A Comparison of the Percentage Uptake of Washed versus Unwashed Red Cells When the Labeled Materials were Dissolved in Human Plasma ably increased (mean 8.3 per cent) over that of labeled sodium iodide (mean 1.9 per cent) and human serum albumin (mean 2.3 per cent). The uptake of labeled L-triiodothyronine was markedly increased (mean 48.2 per cent) above that for L-thyroxine (mean 8.3 per cent) (Figure 1).

\section{Washed red cells-Radioactive tracers in normal saline solution}

The percentage uptake by the washed red cells of the labeled sodium iodide and human serum albumin was again negligible. The uptake of labeled L-thyroxine (mean 56.2 per cent) was markedly increased over that of sodium iodide (mean 2.3 per cent) and human serum albumin (2.5 per cent). This was also a marked increase over that of the uptake of L-thyroxine (mean 8.3 per cent) by the unwashed red cells. The percentage uptake of labeled L-triiodothyronine (mean 74.9 per cent) was increased above that of L-thyroxine and above the percentage uptake in the unwashed cells (mean 48.2 per cent) (Figure 1).

\section{Washed and unwashed red cells-Radioactive tracers in human plasma}

The percentage uptake of the labeled sodium iodide, L-thyroxine, and L-triiodothyronine in plasma by the unwashed red cell was $2.6,7.1$, and 15.0 per cent, respectively. The main difference as compared with radioactive tracers in saline was with L-triiodothyronine, e.g., 48.2 per cent uptake in saline and 15.0 per cent uptake in plasma.

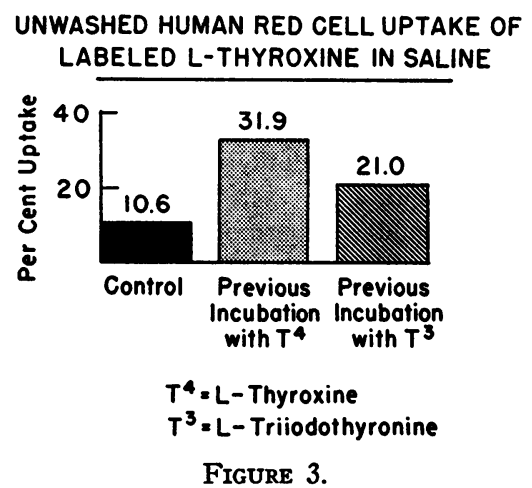

Previous incubation of the unwashed red cell with stable L-thyroxine markedly increases the uptake of the labeled L-thyroxine. L-triiodothyronine incubation increases it to a lesser degree. 
When washed red cells were used, the percentage uptake of the labeled sodium iodide, L-thyroxine, and L-triiodothyronine being 2.2, 8.3, and 15.6 per cent, respectively, did not differ significantly from those obtained with unwashed cells. However, there was a marked difference in the uptake of L-thyroxine and L-triiodothyronine as compared to the uptake by washed red cells when the substances were in normal saline. The uptake of L-thyroxine dropped from 56.2 per cent to 8.3 per cent and L-triiodothyronine from 74:9 per cent to 15 per cent (Figure 2).

Effect of incubating unwashed red cells with stable L-thyroxine and L-triiodothyronine on the uptake of labeled L-thyroxine

The percentage uptake by unwashed red cells of labeled L-thyroxine was definitely increased by previous incubation of the cells with stable L-thyroxine (10.6 per cent to 31.9 per cent). It was increased to a lesser degree by previous incubation of the cells with stable L-triiodothyronine (10.6 per cent to 21.0 per cent) (Figure 3 ).

Effect of adding plasma on the percentage uptake of labeled L-thyroxine by washed red cells

When varying amounts of plasma, varying from .02 to $0.5 \mathrm{ml}$, were added back to washed red cells there was a definite decrease in the percentage uptake of labeled L-thyroxine in saline, i.e., 55 per

WASHED HUMAN RED CELL UPTAKE WITH LABEL DISSOLVED IN SALINE

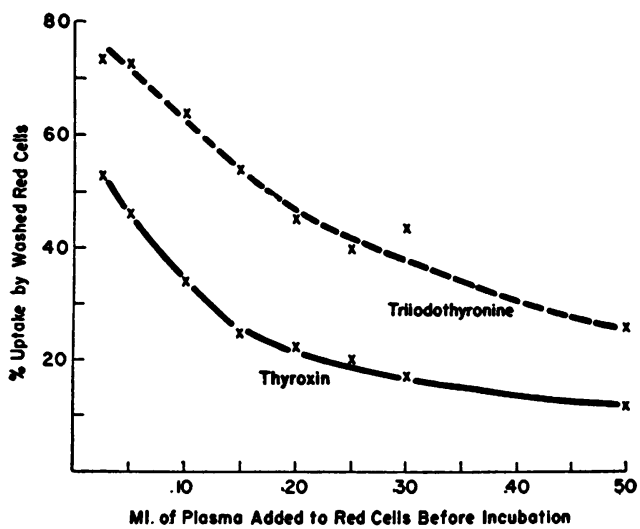

Fig. 4. A Curve Showing that Increasing Amounts of Plasma Added Back to Washed Red Cells Causes a Marked Decrease in the Uptake of Labeled L-THYROXINE AND L-TRIIODOTHYRONINE cent to 10 per cent (Figure 4). The plasma was incubated with stable L-thyroxine before adding it back to the washed red cells. It was impossible to add small enough quantities of plasma to demonstrate a concentration curve unless it was previously incubated with stable L-thyroxine. The uptake of radioactive L-triiodothyronine was also inhibited by the presence of plasma decreasing from 76 per cent to 24 per cent (Figure 4).

\section{DISCUSSION}

The possibility that the uptake or binding ${ }^{3}$ by the red cell of L-thyroxine or L-triiodothyronine is due to contamination with inorganic iodide or a non-specific organic iodinated compound is eliminated by the insignificant uptake by the red cells of radioactive I-131 labeled sodium iodide and iodinated human serum albumin.

Studies from several laboratories $(1-5,6)$ have consistently shown that thyroxine is bound to a serum protein which appears in the electrophoretogram just ahead of alpha-2 globulin (inter-alpha zone). Petermann, Robbins, and Hamilton (7) have further characterized this protein and Schmid (8) found the greatest concentration of protein bound iodine to be in an alpha-glycoprotein fraction.

The studies reported here suggest that in at least one cell, the human erythrocyte, the binding of thyroxine by serum protein is a limiting factor in the uptake ${ }^{4}$ of radioactive I-131 labeled L-thyroxine. The uptake by the unwashed red cell of L-thyroxine dissolved in saline and by the washed red cell of L-thyroxine dissolved in plasma was markedly decreased compared to the uptake by washed red cells of L-thyroxine dissolved in saline. This decreased uptake due to plasma was further demonstrated by the decreasing uptake as increased amounts of plasma were added back to the washed red cells before incubation with the labeled L-thyroxine (Figure 4).

The uptake by the unwashed red cell of labeled L-triiodothyronine was considerably greater than that of the labeled L-thyroxine (Figure 1).

3 To avoid confusion this will be referred to as uptake.

4 It should be emphasized again that by uptake or binding we mean radioactivity that remains with the red blood cell after repeated saline washings. This radioactivity could be within the cell or on the surface of the cell membrane. 
This was also true of the uptake by the washed cells although the difference was considerably reduced due to the marked increase in uptake by the washed red cell of L-thyroxine. The uptake by both washed and unwashed red cells of labeled L-triiodothyronine dissolved in plasma was markedly reduced compared to the saline solution. The above studies suggest that plasma will bind L-triiodothyronine but to a lesser degree than L-thyroxine. This may be due to the triiodothyronineprotein binding which is less specific than thyroxine since triiodothyronine is found in all the electrophoretically distinguishable protein bands (6). The decreased binding of L-triiodothyronine compared to L-thyroxine was also demonstrated by previous incubation of unwashed red cells with stable L-triiodothyronine and L-thyroxine in saline before incubation with labeled L-thyroxine. The uptake was definitely increased by incubation with L-thyroxine but to a lesser degree with L-triiodothyronine (Figure 3 ).

These studies tend to confirm the binding of L-thyroxine by plasma and to show that the in vitro uptake of labeled L-thyroxine by the red cell is markedly decreased in the presence of plasma. The uptake of L-triiodothyronine is also decreased but to a lesser degree. This could be a factor in the more rapid disappearance of L-triiodothyronine from the serum of euthyroid subjects (9). It should be mentioned that the difference in uptake could be due to a greater affinity of the red cells for L-triiodothyronine than for L-thyroxine. These studies do not demonstrate which interpretation is correct.

Hamolsky (10) has presented evidence that there is a qualitative difference in the plasma protein-thyroid hormone complex in the patient with diffuse toxic goitre versus the euthyroid state. This difference was demonstrated by an increased uptake by normal red cells of radioactive I-131 labeled plasma from patients with toxic diffuse goitre. We are attempting to confirm this observation by the methods used in this study. It would appear that this difference is probably due to binding as Dingledine, Pitt-Rivers, and Stanbury (6) were unable to demonstrate any difference in the iodinated compounds of the blood in euthyroid versus hyperthyroid subjects.

\section{SUMMARY}

1. The uptake or binding by the human red blood cell of radioactive I-131 labeled triiodothyronine was consistently greater than the uptake of radioactive $I-131$ labeled thyroxine.

2. The presence of plasma markedly decreased the uptake or binding by the human red cell of radioactive I-131 labeled thyroxine and to a lesser degree the uptake or binding of radioactive I-131 labeled triiodothyronine.

\section{REFERENCES}

1. Gordon, A. H., Gross, J., O'Connor, D., and PittRivers, R., Nature of the circulating thyroid hormone-plasma protein complex. Nature, 1952, 169, 19.

2. Larson, F., Deiss, W. P., and Albright, E. C., Localization of protein-bound radioactive iodine by filter paper electrophoresis. Science, 1952, 115, 626.

3. Deiss, W. P., Albright, E. C., and Larson, F. C., A study of the nature of the circulating thyroid hormone in euthyroid and hyperthyroid subjects by use of paper electrophoresis. J. Clin. Invest., 1952, 31, 1000.

4. Larson, F. C., Deiss, W. P., and Albright, E. C., Radiochromatographic identification of thyroxin in an alpha globulin fraction of serum separated by starch zone electrophoresis. J. Clin. Invest., 1954, 33, 230.

5. Deiss, W. P., Albright, E. C., and Larson, F. C., Comparison of in vitro serum protein binding of thyroxin and triiodothyronine. Proc. Soc. Exper. Biol. \& Med., 1953, 84, 513.

6. Dingledine, W. S., Pitt-Rivers, R., and Stanbury, J. B., Nature and transport of the iodinated substances of the blood of normal subjects and of patients with thyroid disease. J. Clin. Endocrinol. \& Metab., 1955, 15, 724.

7. Petermann, M. L., Robbins, J., and Hamilton, M. G., Sedimentation of the thyroxine-binding protein of serum in the partition cell. J. Biol. Chem., 1954, 208, 369.

8. Schmid, K., Isolation from normal human plasma of $\alpha_{2}$ glycoproteins with low molecular weight. Federation Proc., 1954, 13, 291.

9. Sterling, K., Lashof, J. C., and Man, E. B., Disappearance from serum of $I^{191}$ labeled 1-thyroxine and 1-triiodothyronine in euthyroid subjects. J. Clin. Invest., 1954, 33, 1031.

10. Hamolsky, M. W., The plasma protein-thyroid hormone complex in thyrotoxicosis vs. euthyroidism in man. J. Clin. Invest., 1955, 34, 914. 